\title{
Disinfection of drain water in greenhouses using a wet condensation heater
}

\author{
C Steinberg ${ }^{1 *}$, F Moulin 1, P Gaillard 2, N Gautheron 1, \\ K Stawiecki ${ }^{1}, \mathrm{P}$ Bremeersch ${ }^{1}$, C Alabouvette ${ }^{1}$ \\ ${ }^{1}$ INRA, centre de microbiologie des sols et de l'environnement, laboratoire de flore pathogène du sol, \\ BV 1540, F21034 Dijon cedex; \\ ${ }^{2}$ AIREL, moulin de Murat, Objat, F19130 Voutezac, France
}

(Received 8 August 1994; accepted 30 November 1994)

\begin{abstract}
Summary - A wet condensation heater has been modified to disinfect drain water in greenhouses in addition to providing heating and $\mathrm{CO}_{2}$. Various kinds of microorganisms (bacteria and fungi) and one virus (tobacco mosaic virus [TMV]) originating from either pure cultures or substrate extracts were introduced into the disinfection circuit above the heater. Water was checked downstream for the number of microorganisms surviving the heat treatment. Fungi were destroyed after $30 \mathrm{~s}$ at $58.9^{\circ} \mathrm{C}$, and most of the bacteria except some spore-forming bacteria such as Bacillus polymyxa were destroyed after $45 \mathrm{~s}$ at $65.2^{\circ} \mathrm{C}$. Complete elimination of TMV particles was more difficult to achieve but their number was greatly reduced, limiting the probability of plant infection. The microbial density was significantly decreased at relatively low temperatures (less than $75^{\circ} \mathrm{C}$ for $2 \mathrm{~min}$ ) and so the efficacy of the heater was attributed to a combined effect of both temperature and UV irradiation from the flame. Addition of a nonpathogenic microorganism to the substratum is proposed to compensate for the lack of complete efficiency observed with high flow rates of drain water. This introduced microorganism could occupy the free space and limit an invasion by a pathogen surviving the treatment.
\end{abstract}

disinfection / greenhouse / heat treatment / pathogenic fungus / pathogenic bacteria / recycled drain water / virus

Résumé - Désinfection des eaux de drainage des serres à l'aide d'une chaudière à condensation modifiée. Une chaudière à condensation classiquement utilisée pour fournir du chauffage et du $\mathrm{CO}_{2}$ dans les serres a été modifiée pour en outre permettre la désinfection des eaux de drainage et leur réintroduction dans la circuit d'irrigation. Différents types de micro-organismes (bactéries, champignons) et des particules virales obtenus soit à partir de cultures pures, soit de substrats de culture (sol, Hortifibre ${ }^{\circledR}$ ) ont été introduits dans le circuit de désinfection en amont de la chaudière. Le nombre de micro-organismes survivants dans la solution traitée a été mesuré en sortie de chaudière. Les champignons sont détruits par un passage de $30 \mathrm{~s}$ à $58,9^{\circ} \mathrm{C}$ et la plupart des bactéries testées ne formant pas de spores sont également détruites par un passage de $45 \mathrm{~s}$ à $65,2^{\circ} \mathrm{C}$. Les particules virales sont plus difficiles à éliminer mais leur densité est malgré tout significativement diminuée, réduisant la probabilité d'infection des plantes. La diminution de la densité des micro-organismes étant obtenue à des températures relativement basses (moins de $75^{\circ} \mathrm{C}$ pendant $2 \mathrm{~min}$ ), l'efficacité de la chaudière est attribuée à un effet combiné de la température et des UV produits par la flamme. Cependant, l'efficacité du procédé n'est pas totale pour des débits importants (en période estivale) et, en l'absence de normes indiquant le niveau économiquement acceptable de micro-organismes résiduels que l'on peut tolérer dans l'eau de recirculation, nous suggérons d'introduire dans les substrats de culture un ou des micro-organismes non pathogènes qui limiteraient les possibilités d'invasion par un pathogène survivant au traitement.

bactérie phytopathogène / champignon phytopathogène / eaux de drainage / serre / thermodésinfection / virus

\footnotetext{
${ }^{*}$ Correspondence and reprints
} 


\section{INTRODUCTION}

Plants grown in greenhouses on artificial substrates such as rockwool are overirrigated. The remaining nutrient solution acts as a buffer to prevent too high a ionic imbalance in the root vicinity. Generally, about $20 \%$ of the total nutrient solution is drained and flushed away, resulting in both an economic waste of fertilisers and groundwater pollution problems. To avoid these problems, drain water may be collected and reintroduced into the irrigation system (Runia et al, 1988; Printz, 1994), in which case the sanitary state of the solution must be taken into account. Most of the soil-borne pathogenic microorganisms are likely to be carried through the water flow. This is true for bacteria, such as Erwinia, Clavibacter, Xanthomonas or Pseudomonas, and fungi, such as Fusarium, Pythium or Olpidium; the latter is a virus carrier. On the other hand, the substrates supporting the plants are generally sterile to begin with, but can quickly become sources of infection through the proliferation of microorganisms originated from seeds or contained in drain water. Kritzman (1993) reported that tomato seeds could harbour various pathogenic bacteria. These microorganisms can develop freely in the substrate since their population is not regulated by any microflora. They can then multiply in the drain water with leached fertilisers and spread all over the culture through the irrigation system. Densities of bacteria ranging from $10^{3}$ to $10^{5}$ bacteria $\mathrm{ml}^{-1}$ were detected in the drain water of a tomato culture (Gaillard, 1994). Therefore, this can rapidly and dramatically turn to an epidemic affecting all the plants. Printz (1994) reported that attacks by Phytophthora in ornamental nurseries were significantly higher in plots where drain water was recycled than in plots where it was flushed away. The use of chemical disinfectants is not sufficient to prevent all pathogen development (Koponen et al, 1993); their efficacy is limited in time and some of these disinfectants are phytotoxic such as sodium hypochlorite (Avikainen et al, 1993). Growers must pay particular attention to monitoring the absence of pathogens in the recirculated drain water in order to avoid contamination of the crop (Bates and Stanghellini, 1982; Jenkins and Awere, 1983; MacDonald et al, 1994). One alternative could be disinfection of drainwater. Different processes have been tested: ozonisation, chlorination, ultrafiltration, UV irradiation, heat treatment (Ewart and Chrimes, 1980; Schwartzkopf et al, 1987; Runia, 1991). All of these techniques were rather efficient when tested under laboratory conditions by themselves. Nevertheless, their use is not easy to manage under culture conditions (high salt concentration in water, large stored volume and necessity of cooling system). Thus, the choice of a disinfection system will depend mainly on the constraints of a soilless culture and the basic structures of the greenhouse, rather than on the intrinsic efficiency of the process.

Wet condensation type gas heaters are already in use in some greenhouses to provide both heating and $\mathrm{CO}_{2}$ to the plants. This is why we tested the efficiency of such a gas heater to disinfect pathogen-containing drain water.

\section{MATERIALS AND METHODS}

\section{The heater}

A prototype heater was built by the Compagnie Hortinova (Marseille, France) (fig 1) by modification of a wet condensation-type gas heater (Condenserres P340, A Serres, Eguilles, France) which normally produced hot water $\left(30-50^{\circ} \mathrm{C}\right)$ to heat the greenhouse $(9$ in fig 1), and dry-cleaned the $\mathrm{CO}_{2}$ provided through fume recovery ( 1 in fig 1 ). The heater furnace was modified to ensure the thermodisinfection of irrigation water or recycled nutrient solution simultaneously with water heating and $\mathrm{CO}_{2}$ production. During the process the drain water, heating water and complementary fresh water were pooled in a storage tank ( 8 and 9 in fig 1). Irrigation water and heating water were separated afterwards by means of a dual water circulation system inside the heater body. The first circuit ( 3 in fig 1) circulated the heating water through ceramic Rashig rings ( 7 in fig 1 ) and was connected to a storage tank; the second circuit (4 in fig 1) circulated the irrigation water by means of 4 tubes passing through the ceramic rings. The water in these tubes was therefore preheated before entering into the combustion chamber (6 in fig 1) in which the water flowed at the surface of the cylindrical wall of the chamber. It was then subjected to a brief but intense heat treatment and UV radiation provided by the gas flame (2 in fig 1 ). A temperature probe (12 in fig 1) was set to measure the temperature of the water at the top of the cylindrical chamber. The disinfected water was stored in an irrigation tank (10 in fig 1).

For the purpose of the experiment, the circuit was connected to tap water ( 8 in fig 1). Different flow rates of circulating water in the disinfection circuit were tested $\left(1-5 \mathrm{~m}^{3} \mathrm{~h}^{-1}\right)$. A flow rate of $1 \mathrm{~m}^{3} \mathrm{~h}^{-1}$ involves the water staying in the combustion chamber for $2 \mathrm{~min}$. The time linearly decreased when the flow rate increased. The higher the flow rate, the shorter the time of exposure and the lower the temperature reached by the water to be disinfected. 


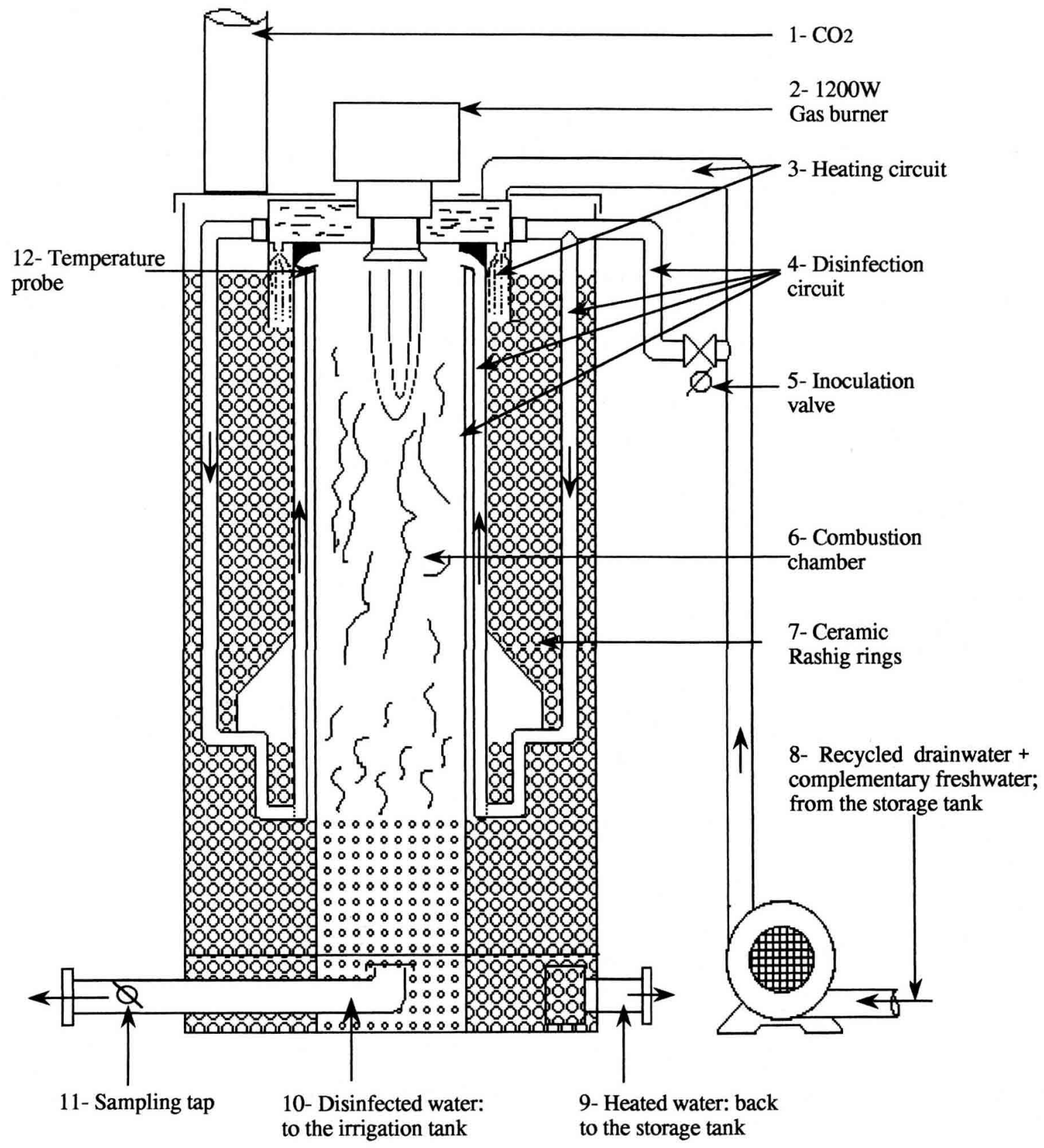

Fig 1. Diagram of the modified wet condensation heater.

\section{Inoculum}

Tests were performed by introducing successively various kinds of inoculum into the disinfection circuit. These inocula were made of microorganisms (table I) chosen as examples of microorganisms likely to be found in drain water. The microorganisms came from i) liquid extracts of used culture substrates containing a mixture of microorganisms, some of which are phytopathogenic; and ii) pure cultures of both pathogenic and non-pathogenic bacteria and fungi, and suspensions of viruses.

\section{Liquid culture of Fusarium}

The Fusarium strain was grown in shake culture on malt broth (malt Difco $10 \mathrm{~g} \mathrm{l}^{-1}$ ) for $5 \mathrm{~d}$. The culture was filtered on a glass fibre filter $(40 \mu \mathrm{m})$ to separate mycelium from conidia. Conidia were then concentrated by centrifugation $(15 \mathrm{~min}, 5000 \mathrm{~g}$ ).

\section{Bacteria}

All the bacteria were previously grown in yeast peptone medium (yeast extract $5 \mathrm{~g}$, peptone Difco $5 \mathrm{~g}$, glu- 
Table I. Inoculum form, strains and respective origin of the microorganims used in the study.

Inoculum

Pure culture

Suspension of TMV

Suspension of microorganisms extracted from Hortifibre ${ }^{\circledR e}$

Suspension of microorganisms extracted from soil ${ }^{\dagger}$
Bacteria Fungi Origin Source

Pseudomonas fluorescens, strain $\mathrm{C7}$

Agrobacterium tumefaciens, strain $\mathrm{C} 58$ biotype 1

Clavibacter michiganensis subsp

michiganensis, strain 1462

Tomato

$\mathrm{CFPBC}^{\mathrm{C}}$

Erwinia carotovora subsp atroseptica, strain 1453

Tomato CFPB

Bacillus polymyxa, strain 1954

Potato

CFPB

Fusarium oxysporum FPFS strain Fo47

Tobacco

LPPd

Pythium spp

Alternaria $\mathrm{sp}$

Unidentified bacteria
Verticillium $\mathrm{sp}$

Penicillium sp

Unidentified fungi

Unidentified bacteria

a FPFS = collection of Flore Pathogène du Sol, INRA, Dijon, France; b EMS = collection of Écologie Microbienne du Sol, Université Lyon, France; ${ }^{c} \mathrm{CFBP}=$ Collection Française de Bactéries Phytopathogènes, Angers, France; ${ }^{d} \mathrm{LPP}=$ collection of Laboratoire Phytoparasitologie, INRA, Dijon, France; e Cucumbers were previously grown on Hortifibre ${ }^{\circledR} ;{ }^{\prime}$ soil: egg plants were previously grown on this soil and showed symptoms of Verticillium.

cose $10 \mathrm{~g}, \mathrm{pH} \mathrm{7,} \mathrm{water} 1000 \mathrm{ml}$ ) for 24-72 $\mathrm{h}$ and then washed with distilled water and concentrated by centrifugation (15 $\mathrm{min}, 6000 \mathrm{~g}$ ).

\section{Substrates}

Two extracts of 2 substrates were used, Hortifibre and soil. Hortifibre ${ }^{\circledR}$ consists of a mixture of poplar fibres torn under water steam to ensure their disinfection and packaged into plastic films. Both Hortifibre extract and soil extract were obtained by grinding 15 times $10 \mathrm{~g}$ of each of the substrates in $100 \mathrm{ml}$ sterile distilled water in a Waring Blender (Eberbach Corp) for $2 \mathrm{~min}$ at high speed. After grinding, the suspensions (about 1.5 । each) were allowed to settle for $5 \mathrm{~min}$. The supernatants were recorded to constitute the inoculum.
The virus suspension (tobacco mosaic virus, TMV) was kindly provided by the Laboratoire de Phytoparasitologie, INRA Dijon, France).

\section{Inoculation}

Each inoculum was introduced into the disinfection circuit above the heater. The suspension was continuously injected for 2-5 min using a pump (5 in fig 1) and according to the flow rate of the circuit and the inoculation value.

As controls, identical injections of microbes were done with the gas furnace off. The microbial densities in the injected suspension were adjusted when possible (ie with bacteria originating from pure culture) to 
reach bacterial population densities in the circulating water similar to those detected by Gaillard (1994) in the drain water of a tomato culture. The samples were taken downtream from the heater. For each given flow rate, 2 samples were taken at $1 \mathrm{~min}$ intervals by means of a tap (11 in fig 1) placed in the circuit. Each sample was divided into 3 subsamples. A tenfold serial dilution was performed for each subsample and the number of microorganisms was determined by the plate count technique using YPA medium (yeast peptone medium + agar $15 \mathrm{~g} / \mathrm{l}$ ) for bacteria and MA (malt + agar $15 \mathrm{~g} / \mathrm{l}$ ) medium for fungi. In the cases when bacteria and fungi were mixed in the suspensions checked, cycloheximide (100 mg/l) and citric acid (250 $\mathrm{mg} / \mathrm{l})$ were added to YPA and MA media to inhibit the growth of fungi and bacteria, respectively. The results are the means of the 6 subsamples. Student $t$-tests were used to compare the results.

The quantity of TMV was determined as follows: a suspension of virus particles was diluted to give a range of $10,5,2.5,1,0.5$ and $0.1 \mathrm{ng}$ virus particles $\mathrm{ml}^{-1}$. Two leaves of two 6 -week-old tobacco plants (Nicotiana tabacum) were used to test each dilution level. The leaves were first gently brushed with carborundum powder, and then with the virus suspension. One week later, the tobacco leaves were checked for the number of necrotic lesions and a linear regression was calculated $(r=0.996 ; y=0.0261 x-0.285$ where $x$ is the mean number of necrotic lesions per leaf and $y$ the virus concentration). The samples thought to contain the viruses were concentrated 9 times by centrifugation in Amicon Centrip 10 tubes (Pharmacia) for 40 min at $3000 \mathrm{~g}$. The concentrated suspension was then tested on tobacco leaves. The mean number of necrotic lesions per leaf was then referred to the linear regression to determine the quantity of virus particles in the sample.

\section{RESULTS}

The results are expressed as colony forming units $(\mathrm{cfu})$ per millilitre of water taken down- stream from the heater. Tables II-IV indicate the number of microorganisms detected in relation to the flow rate, both with the gas furnace off (= control) and on. All the differences between cold control and heat treatment were statistically significant at the $1 \%$ o level unless mentioned in the tables.

The columns on the right-hand sides of tables II-IV indicates the temperature reached by the water when it passed the immediate vicinity of the flame as measured by the probe. It should be noted that a zero result means that microorganisms were not detected in the suspension. The detection limit was 10 bacteria or 1 fungal propagule $\mathrm{ml}^{-1}$ of suspension.

Table II shows that the conidia of Fusarium were easily eliminated at $4 \mathrm{~m}^{3} \mathrm{~h}^{-1}$ or less, ie at a temperature equal to or higher than $58.9^{\circ} \mathrm{C}$.

Table III shows that the efficiency of the heat treatment depends on both the flow rate of the circulating water and the bacterial species. $P$ fluorescens was eliminated whatever the flow rate and with temperatures as low as $59.7^{\circ} \mathrm{C}$ while $B$ polymyxa and to a lesser degree $E$ carotovora were always found in the disinfected water. TMV was more difficult to eliminate. It survived the treatment when the temperature was less than $70^{\circ} \mathrm{C}$.

Table IV shows that complete disinfection was not achieved either when bacteria originated from soil or Hortifibre ${ }^{\circledR}$ suspension. The heater efficacy decreased with increasing flow rate. Moreover, the treatment had no significant effect on the soil suspension at $5 \mathrm{~m}^{3} \mathrm{~h}^{-1}$. Some of the bacteria were roughly identified because of their typical colony morphology: they were either actinomycetes or belonged to the genus Bacillus. Nevertheless not all the colonies were checked

Table II. Number of $F$ oxysporum (Fo47) propagules issued from pure liquid culture surviving the heat treatment compared to the number of $F$ oxysporum in the non-treated (cold control) water.

Flow rate $\left(m^{3} / h\right)$

Number of $\mathrm{F}$ oxysporum propagules

\section{Heat treatment}

$8.1 \times 10^{3}\left(3 \times 10^{2}\right)$

$7.6 \times 10^{5}\left(1.5 \times 10^{3}\right)$

$5.5 \times 10^{3}\left(3.6 \times 10^{2}\right)$

$9.6 \times 10^{3}\left(6.5 \times 10^{2}\right)$

$6.9 \times 10^{3}\left(2.5 \times 10^{2}\right)$
Temperature $\left({ }^{\circ} \mathrm{C}\right)$

$\begin{array}{ll}0 & 73.8 \\ 0 & 69.5 \\ 0 & 62.8 \\ 0 & 58.9 \\ 9.9 \times 10^{2} & 53.5\end{array}$

Number is expressed as cfu ml-1 of water. Differences between cold control and heat treatment were significant at the $1 \%$ level. The numbers in parentheses are standard deviations of the mean. 
Table III. Number of bacteria and TMV particles issued from pure liquid cultures surviving the heat treatment compared to the number of bacteria and TMV particles in the non-treated (cold control) water.

Flow rate $\left(m^{3} h^{-1}\right) \quad$ Pathogen

1

2

3

4

\section{A tumefaciens}

TMV

A tumefaciens

$P$ fluorescens

TMV

$C$ michiganensis

$B$ polymyxa

E caratovora

A tumefaciens

$P$ fluorescens

TMV

$C$ michiganensis

$B$ polymyxa

E carotovora

$P$ fluorescens

Number of cfu $\mathrm{m}^{-1}$

$2.2 \times 10^{3}\left(0.9 \times 10^{2}\right)$

27.8

73.8

73.8

$3.8 \times 10^{5}\left(2 \times 10^{3}\right)$

$5.1 \times 10^{3}\left(2 \times 10^{2}\right)$

14.4

69.5

72.6

69.5

$1.2 \times 10^{5}\left(1 \times 10^{3}\right)$

$3 \times 10^{4}\left(4 \times 10^{2}\right)$

$1.5 \times 10^{5}\left(1.2 \times 10^{3}\right)$

$3.1 \times 10^{3}\left(1.3 \times 10^{2}\right)$

$9.2 \times 10^{3}\left(3 \times 10^{2}\right)$

8.8

0

0.62

$\sim 63$

$8.9 \times 10^{4}\left(1.1 \times 10^{3}\right)$

$1.6 \times 10^{5}\left(2 \times 10^{3}\right)$

$6.5 \times 10^{4}\left(1.1 \times 10^{3}\right)$

$7.5 \times 10^{3}\left(0.9 \times 10^{2}\right)$ $\sim 63$

$\sim 63$

62.1

65.2

62.1

$5.3 \times 10^{2}(23)$

$1 \times 10^{2}(12)$

0

0

2.2

$\sim 59$

$\sim 59$

$\sim 59$

59.7

Number is expressed as cfu ml-1 of water for the bacteria and as nanograms of virus particles as determined by reference to a standard for TMV. The symbol means that the temperature was around $\left( \pm 0.5^{\circ} \mathrm{C}\right)$ the value following the symbol. Differences between cold control and heat treatment were significant at the $1 \%$ level. The numbers in parentheses are standard deviations of the mean.

Table IV. Number of bacteria and fungi issued from a soil suspension and from a Hortifibre suspension surviving the heat treatment compared to the number of the same microorganisms in the non-treated (cold control) water.

Flow rate $\left(m^{3} / h\right)$

Microbe
Number of cfu $\mathrm{ml}^{-1}$

Temperature $\left({ }^{\circ} \mathrm{C}\right)$

\section{Cold control}

Soil suspension

3

4

5

Hortifibre $\left.^{(}\right)$suspension

4

5

Bacteria
Fungi
Bacteria
Fungi
Bacteria
Fungi

Fungi

Bacteria
Fungi

Bacteria

Fungi
$1.6 \times 10^{3}\left(4.5 \times 10^{2}\right)$

$9(0.1)$

$3.1 \times 10^{3}\left(5.5 \times 10^{2}\right)$

20

(0.5)

$2.2 \times 10^{3}\left(4.4 \times 10^{2}\right)$

$18 \quad(0.4)$

$4.8 \times 10^{3}\left(1.5 \times 10^{2}\right)$

$8.5 \times 10^{3}\left(0.8 \times 10^{2}\right)$

$2.2 \times 10^{3}\left(1.3 \times 10^{2}\right)$

$8.5 \times 10^{3}\left(0.8 \times 10^{2}\right)$

Heat treatment

$9.8 \times 10^{2}(15)$ *

0

$1.2 \times 10^{3}\left(10^{2}\right)^{\star \star}$

0

$1.5 \times 10^{3}\left(10^{2}\right)^{(\mathrm{ns})}$

0
66

55.7

Number is expressed as cfu $\mathrm{ml}^{-1}$ of circulating water. Differences between cold control and heat treatment were significant at the $1 \%$ level except: ${ }^{*} 1 \%$ level; ${ }^{*} 5 \%$ level; (ns) non significant. The numbers in parentheses are standard deviations of the means. 
and precisely identified and so it was not possible to draw a conclusion on the species of bacteria able to survive the treatment. Fungi were eliminated at very low temperatures $\left(53.5^{\circ} \mathrm{C}\right)$ in the case of the soil suspension but higher temperatures were needed in the experiment with Hortifibre ${ }^{\circledR}$ suspension.

\section{DISCUSSION}

The efficiency of the heater to disinfect the circulating water depends on the time that the water stays in the combustion chamber. This efficiency was expressed as a percentage of microorganisms eliminated compared with the control.

Besides the flow rate, the heater efficiency varied according to the kind of microorganisms introduced into the disinfection circuit upstream of the heater. Fungi were mostly eliminated whether they originated from pure culture or substrate extracts, except when the flow rate was higher than $4 \mathrm{~m}^{3} \mathrm{~h}^{-1}$. In these cases, the temperature of the water entering the combustion chamber was too low (53.5 or $55.7^{\circ} \mathrm{C}$, tables II and IV) to ensure the killing of the whole fungal population. The morphological state (ie mycelium, conidia or chlamydospore form) of the various fungal species was not checked. Fusarium propagules in the culture suspensions were mostly conidia with few chlamydospores. On the contrary, the kind of propagules that were in the soil and Hortifibre ${ }^{\circledR}$ extract were probably a mixture of mycelium, conidia and many chlamydospores (Couteaudier and Steinberg, 1990). All these propagules were eliminated after a short exposure ( $30 \mathrm{~s}$ to $2 \mathrm{~min}$ according to the flow rate) to temperatures between 58.9 and $73.8^{\circ} \mathrm{C}$. Runia et al (1988) failed to eliminate 29-day-old spores of $F$ oxysporum f sp melongenae, exposed for 2 min to a temperature of $90^{\circ} \mathrm{C}$. In our case, both old (from the Hortifibre ${ }^{\circledR}$ ) and young (from the pure liquid culture) spores were killed. In the case of soil suspension, the chance of recording surviving propagules was very low because of the low initial density of conidia. However, in the case of pure cultures, the chance of recording survival was similar in both Runia's case and in ours since the number of propagules in the suspensions of both experiments was within the same range (ie $2.1 \times 10^{5} \mathrm{cfu} \mathrm{ml}^{-1}$ in Runia's experiments vs $5.5 \times 10^{3}$ to $7.6 \times 10^{5} \mathrm{cfu} \mathrm{ml}^{-1}$ in ours). Because the efficiency of the heater reached $100 \%$ with both a shorter time and a lower temperature of exposure than that reported by Runia et al (1988), the complete disinfection of the drain water was thought to be achieved by a combined effect of both temperature and UV radiation from the flame. Indeed, the temperature of the water at the bottom of the cylindrical chamber could have been higher than that measured at the top because of a longer exposure to the flame. On the other hand, UV radiation, particularly at wavelengths around $254 \mathrm{~nm}$, is known to kill microorganisms by acting on their nucleic acids. Rotem and Aust (1991) showed that the survival of Sclerotium rolfsii, Alternaria macrospora, Aspergillus niger and Botrytis cinerea was affected when these fungi were exposed to UV irradiation. Nevertheless, the efficiency of UV irradiation depended on the fungal species. $S$ rolfsii was rather resistant while $B$ cinerea was killed by a 3-min exposure. Stanghellini et al (1984) succeeded in controlling root rot of spinach caused by Pythium aphanidermatum by UV irradiation in a recirculating hydroponic system.

This combined action must also have occurred on bacteria. A range of 5 bacterial species including 3 pathogenic species was checked. Depending on the genus, some of them were very sensitive such as $P$ fluorescens, while others could survive. The efficiency of the heater was high (more than $98 \%$ ) but it may not be acceptable to have a low inoculum density of $B$ polymyxa or $E$ carotovora in the recirculating water. The persistence of $B$ polymyxa and to a lower extent of $C$ michiganensis could be explained by the fact that these bacteria are Gram-positive bacteria, with a stronger cell wall which renders them less sensitive. Moreover, $B$ polymyxa cells can form resting spores that may resist even more. Belliveau et al (1990) have shown that the heat resistance of $B$ megaterium spores could be correlated with their DNA content, ie with multiple genome copies. Only 1 undamaged copy would be necessary to ensure the survival of the bacteria. In that case, the survival of $E$ carotovora cells is more difficult to explain as they are Gram-negative bacteria but the hypothesis of heat shock proteins induced during the preheating phase and conferring heat resistance could be tested.

Unidentified bacteria from the soil suspension and to a lesser extent from the Hortifibre ${ }^{\oplus}$ suspension were less affected by the treatment. The efficiency of the heater was less than $60 \%$ in the former case and less than $85 \%$ in the latter. One explanation could be that soil-borne bacteria are much more diverse in their susceptibility to high temperatures than bacteria originating from a cul- 
tivated clonal population. Therefore, some resistant bacteria could have been unaffected by the heat shock. Moreover, soil-borne bacteria were probably protected from both the UV radiation and the heat shock by some soil particles such as clay particles that are known to protect microorganisms in soil (Stotzky, 1966). When extracted from soil, bacteria may be embedded in clay particles and survive the treatment.

To our knowledge, data concerning the elimination of viruses from drain water are rather scarce. The concentrations used in our experiments were high and the treatment reduced the inoculum but with an efficiency of 100, 95 and $75 \%$ when the flow rates were 1,2 and $3 \mathrm{~m}^{3} \mathrm{~h}^{-1}$ respectively. Because viruses do not multiply on their own, it can be concluded that the treatment greatly reduced the probability of a virus infection.

One problem thay may occur is that UV irradiation could provoke iron dechelation depending on the kind of Fe-chelate used in the nutrient solution (Schwartzkopf et al, 1987). Iron precipitates from the solution resulting in iron chlorosis. Iron concentration was not assessed in our experiments. Obviously, such chemical measurements will have to be made in further trials.

\section{CONCLUSION}

The requirements that force the recirculation of crop effluents in greenhouses obviously introduce the risk of spreading pathogens within crops. In our study, complete disinfection of drain water was achieved for low flow rates. Depending on the stage of the crop and the season, the volume of drain water to disinfect can be low, in which case, the process combining UV radiation with short exposure to temperature is a good way of recirculating drain water with a very limited risk of pathogen propagation. Moreover, this combined effect will result in a lower energy consumption. However, in summer, more drain water must be disinfected and a flow rate of $1 \mathrm{~m}^{3} \mathrm{~h}^{-1}$ could be a limiting factor. This could involve a continuous running of the heater resulting in an overproduction of $\mathrm{CO}_{2}$, an overheating of the heating water and thus a need for coolers. Such a solution does not seem to be reasonable. A pathologist needs $100 \%$ efficiency because an efficiency of $98.75 \%$ results in $1.25 \%$ microorganisms left (ie $2 \times 10^{3}$ bacteria $\mathrm{ml}^{-1}$ in the case of $B$ polymyxa (table III) which is a high inoculum potential). However, a grower could accept a tolerance threshold if the presence of microorganisms in the drain water does not imply an economic risk. There is a real need to get information to establish rational, economical drain water quality standards, ie acceptable propagule residuals. Biotests that allow the estimation of the infection potential of the drain water could be performed but they cannot be used in practice to advise the growers (Moulin et al, 1994). An alternative solution would be the massive introduction of selected biocontrol agents downstream from the heater (Steinberg, 1991). These microorganisms, selected for their antagonistic activity in a given rhizosphere, would thus outcompete the surviving pathogens (Alabouvette et al, 1987). Introducing selected microorganisms into the culture substrate and through the nutrient solution or the drain water will result in an occupation of the niches and will thus limit infestation by a pathogen. Some biocontrol agents have already been selected for their antagonistic activity against pathogens (Alabouvette, 1991, 1993) and could overcome the limited efficiency of the heater. Such a combination would constitute a low-cost method in recirculating drain water safely.

\section{ACKNOWLEDGMENTS}

The authors wish to thank $Y$ Dalle and $M$ Serre from the Compagnie Hortinova (Marseille, France) for providing the wet condensation heater.

\section{REFERENCES}

Alabouvette C (1991) Suppressive soils and practical application of biological control of Fusarium diseases. In: The Biological Control of Plant Diseases and Virus Vectors (H Komada, K Kiritani, J BayPetersen, eds), FFTC, Taipei, Taiwan, 120-129

Alabouvette $C$, De La Broise D, Lemanceau $P$, Couteaudier $Y$, Louvet $J$ (1987) Utilisation de souches non pathogènes de Fusarium pour lutter contre les fusarioses. Situation actuelle dans la pratique. EPPO Bull 17, 665-674

Alabouvette C, Lemanceau P, Steinberg C (1993) Recent advances in the biological control of Fusarium wilts. Pestic Sci 37, 365-373

Avikainen $\mathrm{H}$, Koponen $\mathrm{H}$, Meinander $\mathrm{B}$, Tahvonen $\mathrm{R}$ (1993) The phytotoxicity of disinfectants and their effect at different temperatures. Agric Sci Fin/ 2, 161-16

Bates ML, Stanghellini ME (1982) Root rot of hydroponic-grown spinach caused by Pythium aphanider- 
matum and Pythium dissotocum (abstr). Phytopathology 63, 1490-1501

Belliveau BH, Beaman TC, Gerhardt P (1990) Heat resistance correlated with DNA content in Bacillus megaterium spores. App/ Environ Microbiol 56, 2919-2921

Couteaudier Y, Steinberg C (1990) Biological and mathematical description of the growth pattern of Fusarium oxysporum in a sterilized soil. FEMS Microbiol Ecol 74, 253-260

Ewart JM, Chrimes JR (1980) Effects of chlorine and ultra-violet light in disease control in NFT. Acta Hortic 98, 317-323

Gaillard P (1994) La thermodésinfection des eaux d'irrigation pour les cultures de tomate hors sol. Mémoire d'ingénieur des techniques agricoles, ENESAD-INPSA Dijon, France

Jenkins SF, Awere CW (1983) Root diseases of vegetables in hydroponic culture systems in North Carolina greenhouses. Plant Dis 67, 968-970

Koponen H, Avikainen $H$, Tahvonen R (1993) The effect of disinfectants on fungal diseases of potato and vegetables. Agric Sci Fin/2, 169-177

Kritzman G (1993) A chemi-thermal treatment for control of seedborn bacterial pathogens of tomato. Phytoparasitica 21, 101-109

MacDonald JD, Ali-Shtayeh MS, Kabashima J, Stites J (1994) Occurrence of Phytophtora species in recirculated nursery irrigation effluents. Plant Dis 78 , 607-611
Moulin F, Lemanceau P, Alabouvette C (1994) Pathogenicity of Pythium species on cucumber in peat-sand, rockwood and hydroponics. Eur J Plant Pathol 100, 3-17

Printz P (1994) La pépinière à l'heure du recyclage. Compte rendu de la commission Conteneurs du CPA. PHM Revue Hortic 346, 23-26

Rotem J, Aust HJ (1991) The effect of ultraviolet and solar radiation and temperature on survival of fungal propagules. J Phytopathol 133, 76-84

Runia TW, Van Os EA, Bollen GJ (1988) Disinfection of drain water from soilless cultures by heat treatment. Neth J Agric Sci 36, 231-238

Runia TW (1991) Désinfection et recirculation de la solution nutritive. Grodan info 24, 6-7

Schwartzkopf SH, Dudzinski D, Minners RS (1987) The effects of nutrient solution sterilization on the growth and yield of hydroponically grown lettuce. Hortic Sci 22, 873-874

Stanghellini ME, Stowell LJ, Bates ML (1984) Control of root rot of spinach caused by Pythium aphanidermatum in a recirculating hydroponic system by ultra-violet irradiation. Plant Dis 68, 1075-1076

Steinberg C (1991) Efficacité d'un système original de thermodésinfection. Grodan Info 24, 7

Stotzky G (1966) Influence of clay minerals on microorganisms. II. Effect of various clay species, homoionic clays and other particles on bacteria. Can J Microbiol 12, 831-848 